\title{
Variation in water and sucrose responsiveness during the foraging season affects proboscis extension learning in honey bees
}

\author{
Ricarda SCHEINER*, Marcus BARNERT, Joachim ERBER \\ Institut für Ökologie, Technische Universität Berlin, Franklinstr. 28/29, 10587 Berlin, Germany
}

(Received 21 March 2002; revised 28 June 2002; accepted 31 July 2002)

\begin{abstract}
Honey bee foragers often show a variation in laboratory proboscis extension learning during the foraging season, making comparisons between experiments difficult. We analysed whether the seasonal variation in learning performance was related to a variation in sucrose responsiveness in pollen and nonpollen foragers. Pollen foragers were very responsive to water and sucrose throughout the season. Nonpollen foragers were overall less responsive and showed more variation. Sucrose responsiveness strongly correlated with tactile and olfactory learning performance in pollen and non-pollen foragers throughout the season. Learning performance was significantly better when sucrose responsiveness was high than when it was low. We suggest conditioning bees that have uniform sucrose responsiveness throughout the season to reduce experimental variance.
\end{abstract}

Apis mellifera / proboscis extension response / learning / responsiveness to sucrose / seasonal variation

\section{INTRODUCTION}

Most analyses of the physiological mechanisms underlying learning in honey bees use the proboscis extension response (PER) for conditioning under laboratory conditions (Bitterman et al., 1983; Menzel and Müller, 1996; Erber et al., 1998). In these experiments, a conditioned stimulus (CS), typically an odour or a tactile stimulus, is presented to the honey bee (Apis mellifera L.). Then proboscis extension is elicited by briefly touching the antennae with sucrose solution representing the unconditioned stimulus (US). The PER is rewarded by allowing the bee to drink a small volume $(1-2 \mu \mathrm{L})$ of sucrose solution. When the CS is presented again after conditioning, a high proportion of bees respond with probos- cis extension. The success rate of PER conditioning varies strongly during the foraging season, which makes comparisons between experiments conducted at different times difficult. The reasons for this variation in learning performance are unknown.

Earlier experiments showed that sucrose responsiveness, which was largely determined by genotype and foraging role, affects acquisition in PER learning (Scheiner et al., 2001a, b). But those experiments were always conducted in a very small time window. It is unknown how sucrose and water responsiveness change during the course of the foraging season and whether a possible variation in responsiveness correlates with learning performance during the season.

\footnotetext{
* Correspondence and reprints

E-mail: rici0734@mailszrz.zrz.tu-berlin.de
} 


\section{MATERIALS AND METHODS}

This study was conducted during the 1999 foraging season in Berlin, Germany (longitude 13 $3^{\circ} 40^{\prime} \mathrm{E}$, latitude $52^{\circ} 47^{\prime} \mathrm{N}$ ). We used bees from a breeder line considered as Apis mellifera carnica with a naturally-mated queen. Returning foragers were caught between 09:00 and 10:00 h (local time) in the morning at the hive entrance. Pollen foragers were identified by their pollen loads. Bees returning without pollen loads were regarded as non-pollen foragers. These bees were most likely nectar foragers, because younger bees departing for their orientation flights only leave the hive at noon or in the afternoon (von Frisch, 1965; Winston, 1987), and water collectors are a very small subgroup of the foragers (Seeley, 1995). As in many other studies on PER learning in honey bees (Takeda, 1961; Bitterman et al., 1983; Thorn and Smith, 1997; Menzel, 1999), the age of the foragers was not controlled for.

After collection, the bees were immobilized by cooling them in individual glass vials in a refrigerator maintained at $4{ }^{\circ} \mathrm{C}$. Bees were placed in small metal holders, with strips of adhesive tape attached between head and thorax and over the abdomen. Prior to the experiments, each bee was fed with approximately $5 \mu \mathrm{L}$ of a $30 \%$ sucrose solution. This feeding ensured that bees did not starve before their sucrose responsiveness was measured. In independent experiments we found that feeding of $5 \mu \mathrm{L}$ of sucrose did not significantly affect sucrose responsiveness $(P>0.05, \mathrm{n}=24$, two-tailed Wilcoxon test). One hour after mounting, the following sucrose concentrations were applied to the antennae of each bee in ascending order: $0.1 \%, 0.3 \%, 1 \%$, $3 \%, 10 \%, 30 \%$ (weight/volume). Prior to each sucrose stimulation we applied water to the antennae to test water responsiveness. The inter-trial interval was 3 minutes.

The sum of responses to all 6 sucrose concentrations represents the sucrose score of each bee, which is a reliable indicator of the individual responsiveness to sucrose (Page et al., 1998; Scheiner et al., 1999, 2001a, b). Bees with high sucrose scores respond to low concentrations of sucrose. In the same way the water score was calculated for each bee by adding the total number of proboscis responses to the 6 water stimulations. Both scores vary between 0 and 6 . The scores were always measured on a fixed day during the season to avoid experimental bias.

Proboscis extension learning during the same season was studied in bees whose individual sucrose scores were measured before conditioning. The bees were trained to tactile stimuli or odours. During tactile learning, each bee could scan a small plate $(3 \times 4 \mathrm{~mm})$ with vertical grooves (wave- length: $450 \mu \mathrm{m}$, width: $150-190 \mu \mathrm{m}$, depth: 30 $40 \mu \mathrm{m}$, see Erber et al., 1998). In olfactory learning, the odour citral was delivered in a controlled airstream through a vial containing a filter paper soaked with $2 \mu \mathrm{L}$ of the odour. In each experiment, the CS was presented $3 \mathrm{~s}$ before the PER was elicited by applying a droplet of $30 \%$ sucrose solution to either antenna. The bee was then allowed to drink from this droplet for $1 \mathrm{~s}$. At the beginning of the next conditioning trial, the CS was presented and it was recorded whether the bee showed a conditioned PER. If the bee showed proboscis extension at the presentation of the CS, it was allowed to drink from the sucrose droplet for $1 \mathrm{~s}$. If the bee did not show the conditioned PER, proboscis extension was elicited by stimulating its antennae with sucrose and the bee was subsequently allowed to drink sucrose as before. In both experiments the bees were conditioned 6 times. The total number of conditioned proboscis extensions represents the acquisition score of a bee. All experiments were conducted in a laboratory room.

Water scores, sucrose scores and acquisition scores were averaged over 4-week intervals during the season for pollen and non-pollen foragers. For graphic display, mean sucrose and acquisition scores were calculated. To test for an overall variation in sucrose scores of pollen and non-pollen foragers, the two-tailed Kruskal-Wallis test was applied. The scores of different intervals and those of pollen and non-pollen bees were compared with the two-tailed Mann-Whitney U-test (SPSS 9.0). Mean differences of the sucrose scores between pollen and non-pollen foragers were calculated for each of the 4-week intervals. To test for correlations between sucrose scores and water scores and between sucrose scores and tactile or olfactory acquisition scores Spearman rank correlations were calculated.

\section{RESULTS}

Sucrose responsiveness, as measured by sucrose scores, showed a significant variation over the different weeks of the season in both pollen and non-pollen foragers (Tab. I, nonpollen foragers: $\chi^{2}=32.86$, pollen foragers: $\chi^{2}=16.91, P=0.001$, two-tailed KruskalWallis-Test). Pollen foragers demonstrated their highest responsiveness at the end of May (Fig. 1A, Tab. I) but otherwise showed little variation. Non-pollen foragers showed their lowest responsiveness in June and July (Fig. 1A, Tab. I) and were more responsive before and after that period. 
Table I. Matrix of significant differences between sucrose scores of different 4-week intervals shown in Figure 1A for pollen and non-pollen foragers. *: $P=0.05$, **: $P=0.01$, ***: $P=0.001$, two-tailed MannWhitney U-test. po: pollen foragers. np: non-pollen foragers, n.s.: not significant.

\begin{tabular}{ccccccccccccc}
\hline $\begin{array}{c}\text { Experim. } \\
\text { weeks }\end{array}$ & \multicolumn{2}{c}{$1-4$} & \multicolumn{2}{c}{$5-8$} & & \multicolumn{2}{c}{$9-12$} & & $13-16$ & & $17-20$ & $21-24$ \\
\hline & po & np & po & np & po & np & po & np & po & np & po & np \\
$1-4$ & - & - & - & - & - & - & - & - & - & - & - & - \\
$5-8$ & $*$ & n.s. & - & - & - & - & - & - & - & - & - & - \\
$9-12$ & n.s. & $* * *$ & $*$ & $* * *$ & - & - & - & - & - & - & - & - \\
$13-16$ & n.s. & $*$ & $* *$ & $*$ & n.s. & $* * *$ & - & - & - & - & - & - \\
$17-20$ & n.s. & n.s. & n.s. & n.s. & n.s. & $* * *$ & n.s. & $*$ & - & - & - & - \\
$21-24$ & n.s. & n.s. & $* * *$ & n.s. & n.s. & $* * *$ & n.s. & $*$ & $* *$ & $*$ & - & - \\
\hline
\end{tabular}
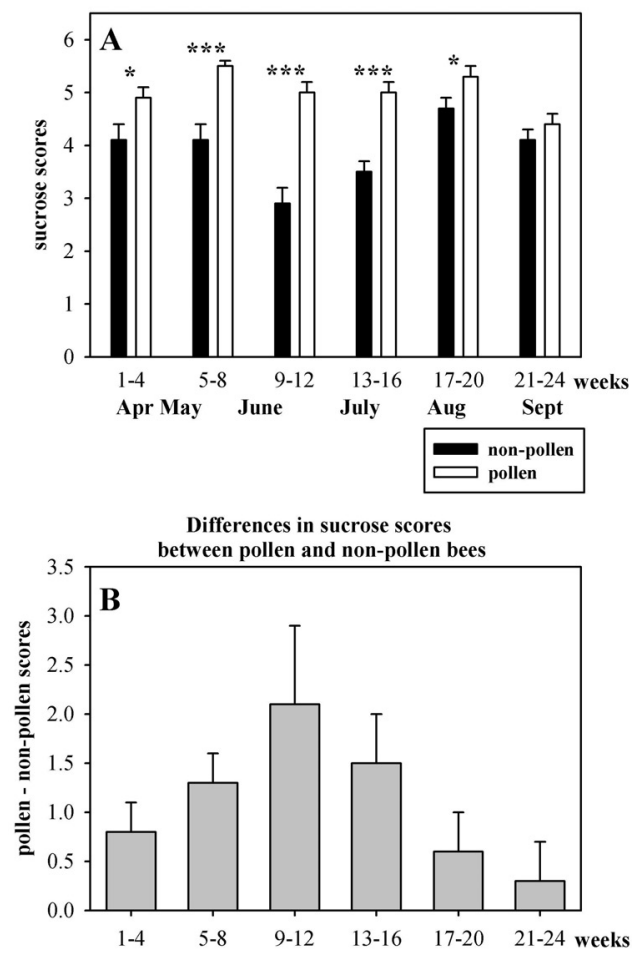

Figure 1. A. Sucrose responsiveness of pollen and non-pollen foragers measured in 4-week intervals during 1999. The experimental weeks and the months are indicated on the abscissa. The graphs show mean sucrose scores and standard errors of the means (SEM). Significant differences between pollen and non-pollen foragers are indicated by asterisks (*: $P=0.05$, ***: $P=0.001$, two-tailed Mann-Whitney U-test). Each data point represents approximately 80 bees. B. Differences in sucrose scores of pollen and non-pollen foragers. The graphs show means and SEM.
In general, pollen foragers were more responsive to sucrose than non-pollen foragers (Fig. 1A). The differences in sucrose scores between pollen and non-pollen foragers reached a maximum in June (Fig. 1B). Water scores correlated highly significantly with sucrose scores for pollen and non-pollen foragers (pollen foragers: rho $=0.777, \mathrm{n}=505$, $P=0.001$, non-pollen foragers: $r h o=0.862$, $\mathrm{n}=507, P=0.001$, Spearman rank correlation).

Randomised groups of pollen and non-pollen foragers were selected from the above sample for associative tactile and olfactory learning experiments in 4-week intervals over the first 16 weeks of the study. As sucrose and water scores showed significant correlations, we only analysed the dependencies of acquisition scores on sucrose scores in the two groups of foragers. Sucrose scores of pollen and nonpollen foragers (Fig. 2A, C) strongly correlated with performance in tactile (Fig. 2B) and olfactory (Fig. 2D) acquisition (tactile conditioning of pollen foragers: rho $=0.635, P \leq$ $0.001, \mathrm{n}=55$, olfactory conditioning of pollen foragers: rho $=0.436, P \leq 0.001, \mathrm{n}=55$; tactile conditioning of non-pollen foragers: rho $=$ $0.69, P \leq 0.001, \mathrm{n}=55$; olfactory conditioning of non-pollen foragers: rho $=0.403, P \leq 0.01$, $\mathrm{n}=55$; Spearman rank correlation). Differences in the sucrose scores of pollen and nonpollen foragers correlated with differences in the tactile and olfactory acquisition scores (Fig. 2).

Our experiments demonstrate that the differences in sucrose responsiveness between pollen and non-pollen foragers were not constant 

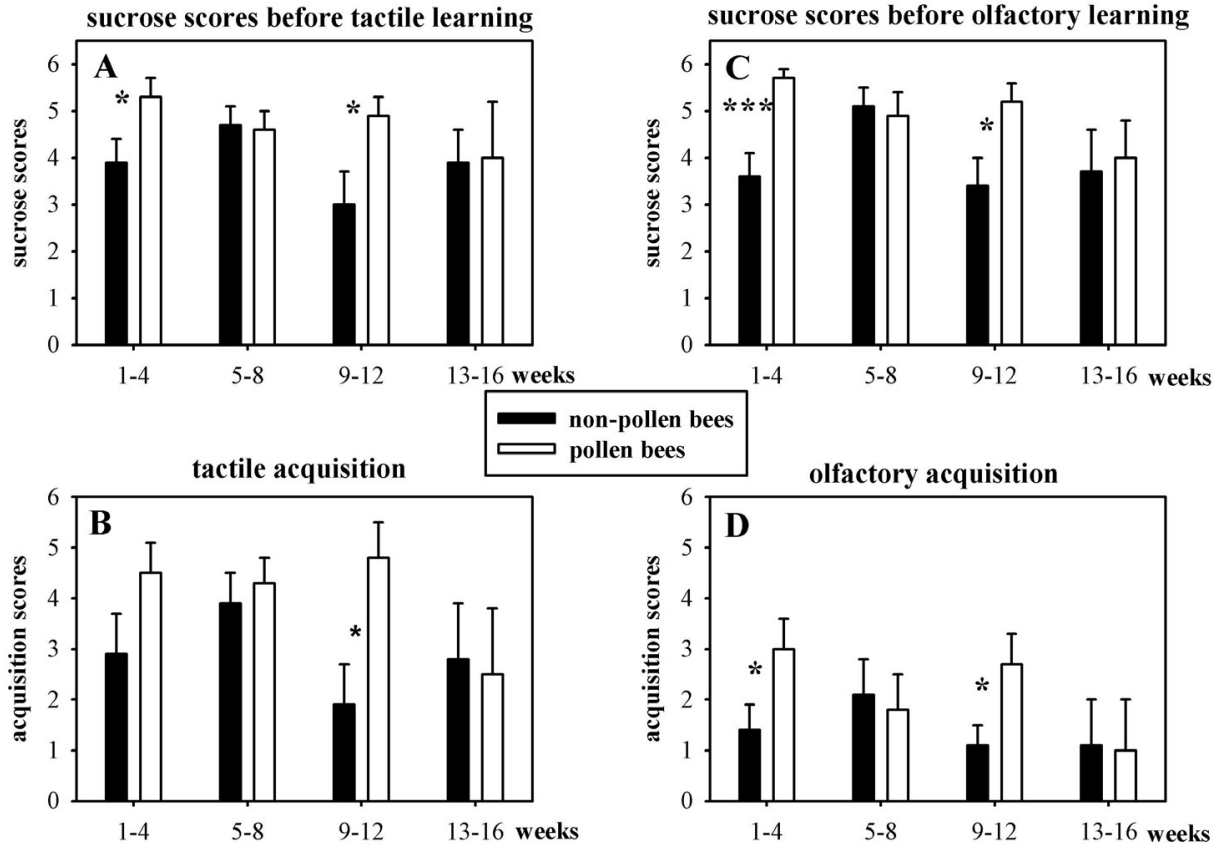

Figure 2. Mean sucrose and acquisition scores and SEM for different 4-week intervals. The weeks are indicated on the abscissae and correspond to Figure 1. A. Sucrose scores of non-pollen and pollen foragers that were conditioned to a tactile pattern. B. Tactile acquisition scores of the bees shown in A. Number of bees tested: non-pollen foragers weeks 1-4: 14, 5-8: 23, 9-12: 10, 13-16: 8; pollen foragers weeks 1-4: 15, 5-8: 24, 9-12: 12, 13-16: 4. C. Sucrose scores of non-pollen and pollen foragers that were conditioned to citral. D. Olfactory acquisition scores of the bees shown in C. Number of bees tested: non-pollen foragers weeks 1-4: 19, 5-8: 13, 9-12: 16, 13-16: 7; pollen foragers weeks 1-4: 19, 5-8: 15, 9-12: 15, 13-16: 7 . Significant differences between pollen and non-pollen foragers are indicated by asterisks $(*: P=0.05$, ***: $P=0.001$; two-tailed Mann-Whitney U-test).

over the season. Consequently, the learning performance varied considerably during the year between these two groups of foragers.

\section{DISCUSSION}

In most of the 4-week experimental intervals, pollen foragers were more responsive to water and sucrose than non-pollen foragers. The difference in responsiveness between the two groups of bees was not constant over the time of the experiments but demonstrated a time-dependence, leading to particularly great differences in June. At the end of the foraging season, in September, responsiveness of pollen and non-pollen foragers converged. This result is the first quantitative demonstration of the time-dependent variations of gustatory responsiveness in two groups of foragers over the foraging season and supports earlier findings demonstrating that pollen foragers are generally more responsive to water and sucrose than non-pollen foragers (Page et al., 1998; Scheiner et al., 1999, 2001b).

Both pollen and non-pollen foragers showed variations in sucrose responsiveness over the different 4-week intervals. For nonpollen foragers this became particularly apparent in June and July, when responsiveness was significantly lower than before and after that period. The modulation of sensory responsiveness depends on a number of internal colonyspecific and external environmental parameters which have been only partially identified. In addition to the known effects of genotype (Page et al., 1998; Scheiner et al., 2001a, b), brood pheromone (Pankiw and Page, 2001), feeding and foraging experience on sucrose 
responsiveness (Pankiw et al., 2001), factors such as weather, floral resources, and the amount of honey stored in the colony probably modulate responsiveness in a very complex way.

Sucrose responsiveness correlated strongly with acquisition of citral and tactile cues in pollen and non-pollen foragers throughout the season. Earlier experiments showed that sucrose responsiveness could explain differences in tactile and olfactory learning of bees with different genotypes, foraging roles or ages (Pankiw and Page, 1999; Scheiner et al., 1999, 2001a, b). This study shows for the first time that the modulation of sucrose responsiveness by complex colony and environmental parameters correlated with large variations of PER learning performance over the season. Our results provide an explanation for the finding of Ray and Ferneyhough (1997) that indoor colonies have almost no variation in learning performance during the year, whereas outdoor colonies show large seasonal effects on learning. In indoor colonies, the variations of environmental and intra-colonial factors were small throughout the year, while these parameters can change significantly for outdoor colonies during the foraging season.

Why the olfactory acquisition scores were generally lower than the tactile learning scores is unclear. In similar experiments using the same two protocols under different climatic conditions, the two paradigms yielded similar conditioning success (Scheiner et al., 2001a).

Our experiments show quantitatively that the variation in learning performance of bees during the foraging season was related to their changing sucrose responsiveness. The multiple parameters for the variation in sucrose responsiveness need further study. We suggest that the variation in learning performance of bees tested at different times can be strongly reduced by selecting bees with uniform sucrose responsiveness.

\section{ACKNOWLEDGEMENTS}

This work was supported by the Deutsche Forschungsgemeinschaft (SFB 515). We thank Karin Grandy for her help with the experiments. The experiments we conducted comply with the current guidelines of Germany for the proper treatment of animals.
Résumé - La variation dans la sensibilité à l'eau et au saccharose au cours de la saison de butinage agit sur l'apprentissage de l'extension du proboscis chez l'Abeille domestique. L'Abeille domestique (Apis mellifera L.) peut être entraînée à étendre son proboscis lorsqu'on stimule ses antennes par une odeur ou un stimulus tactile. La performance de l'apprentissage d'une odeur ou d'un stimulus tactile varie au cours de l'année, ce qui peut rendre très difficiles les comparaisons entre expériences faites à divers moments de l'année. La sensibilité individuelle à l'eau et au saccharose peut être facilement mesurée en appliquant de l'eau et une série de concentrations de saccharose sur l'antenne d'une abeille, ce qui provoque la réponse d'extension du proboscis (PER). Il a été montré dans des expériences antérieures que la sensibilité individuelle au saccharose peut expliquer les différences d'apprentissage entre abeilles de différents génotypes, entre abeilles ayant différents rôles dans le butinage et entre abeilles d'âge différent. Dans cette étude nous analysons si la sensibilité individuelle à l'eau et au saccharose varie au cours de l'année chez deux types de butineuses, celles qui récoltent du pollen et celles qui n'en récoltent pas, et si les différences dans la sensibilité au saccharose peuvent expliquer les différences d'apprentissage observées au cours de la saison de butinage.

La sensibilité au saccharose a varié au cours de la saison de butinage chez les deux types de butineuses mais les butineuses de pollen ont été plus sensibles que les autres (Fig. 1, Tab. I). Les performances de l'apprentissage associatif tactile et olfactif étaient fortement corrélées avec la sensibilité au saccharose chez les deux types d'abeilles. Les performances d'apprentissage étaient meilleures aux périodes où la sensibilité au saccharose était plus forte (Fig. 2). Nos expériences montrent pour la première fois que les différences d'apprentissage à différentes périodes de la saison de butinage sont corrélées avec une variation dans la sensibilité au saccharose. Afin d'obtenir des résultats similaires tout au long de l'année, nous suggérons de n'entrâner que des abeilles qui ont la même sensibilité au saccharose.

Apis mellifera / apprentissage / PER / sensibilité au saccharose / variation saisonnière

Zusammenfassung - Variation der Empfindlichkeit für Wasser und Zucker während der Trachtsaison bewirkt Lernunterschiede des Rüsselreflexes bei Honigbienen. Honigbienen können unter Laborbedingungen darauf konditioniert werden, bei Präsentation eines taktilen Stimulus oder eines Duftes ihren Rüssel herauszustrecken. Die Lernrate im Duftlernen und im taktilen Lernen schwankt während eines Jahres, was Vergleiche 
zwischen Experimenten, die zu verschiedenen Zeitpunkten durchgeführt wurden, sehr erschwert. Bei Bienen ist die Empfindlichkeit für Wasser und Zuckerwasser mittels der Rüsselreaktion leicht meßbar. Werden die Antennen einer Biene mit einem Tropfen Zuckerlösung berührt, so streckt die Biene ihren Rüssel heraus. Die individuelle Empfindlichkeit einer Biene für Wasser und Zuckerwasser kann gemessen werden, indem die Antennen einer Biene mit Wasser und Zuckerlösungen aufsteigender Konzentration berührt werden. In früheren Experimenten konnte gezeigt werden, daß die individuelle Empfindlichkeit für Zuckerwasser Lernunterschiede zwischen Bienen verschiedenen Genotyps, Bienen mit verschiedener Sammelrolle und zwischen Bienen verschiedenen Alters erklären kann. In dieser Studie untersuchten wir, ob sich in Pollen- und Nicht-Pollensammlerinnen die individuelle Empfindlichkeit für Wasser und Zuckerwasser im Laufe eines Jahres ändert und ob Unterschiede in der Zuckerwasserempfindlichkeit Lernunterschiede innerhalb der Sammelsaison erklären können. Die Empfindlichkeit für Wasser und Zuckerwasser änderte sich im Laufe der Sammelsaison sowohl in Pollen als auch in Nicht-Pollensammlerinnen, aber Pollensammlerinnen waren zumeist empfindlicher als Nicht-Pollensammlerinnen (Abb. 1, Tab. I). Die Lernrate im assoziativen taktilen und olfaktorischen Lernen korrelierte stark mit der Zuckerwasserempfindlichkeit in beiden Gruppen. Die Lernrate war höher zu Zeiten, wo die Zuckerwasserempfindlichkeit hoch war, als wenn diese gering war (Abb. 2). Unsere Experimente zeigen damit erstmalig, daß Lernunterschiede zu verschiedenen Zeitpunkten der Sammelsaison mit Änderungen der Zuckerwasserempfindlichkeit korrelieren. Um vergleichbare Ergebnisse in Lernexperimenten, die zu verschiedenen Zeitpunkten im Jahr durchgeführt werden, zu erhalten, sollten deshalb Bienen mit gleicher Zuckerwasserempfindlichkeit konditioniert werden.

\section{Honigbiene / Rüsselreflex / Empfindlichkeit für Zuckerwasser / saisonale Variation}

\section{REFERENCES}

Bitterman M.E., Menzel R., Fietz A., Schäfer S. (1983) Classical conditioning of proboscis extension in honeybees (Apis mellifera), J. Comp. Physiol. 97, 107-119.
Erber J., Kierzek S., Sander E., Grandy K. (1998) Tactile learning in the honeybee, J. Comp. Physiol. A 183, 737-744.

Frisch K. von (1965) Tanzsprache und Orientierung der Bienen, Springer-Verlag, Berlin, Heidelberg, New York.

Menzel R. (1999) Memory dynamics in the honeybee, J. Comp. Physiol. A 185, 323-340.

Menzel R., Müller U. (1996) Learning and memory in honeybees: from behavior to neural substrates, Rev. Neurosci. 19, 379-404.

Page R.E., Erber J., Fondrk M.K. (1998) The effect of genotype on response thresholds to sucrose and foraging behavior of honey bees (Apis mellifera L.), J. Comp. Physiol. A 182, 489-500.

Pankiw T., Page R.E. (1999) The effect of genotype, age, sex, and caste on response thresholds to sucrose and foraging behavior of honey bees (Apis mellifera L.), J. Comp. Physiol. A 185 , 207-213.

Pankiw T., Page R.E. (2001) Brood pheromone modulates honeybee (Apis mellifera L.) sucrose response thresholds, Behav. Ecol. Sociobiol. 49, 206-213.

Pankiw T., Waddington K.D., Page R.E. (2001) Modulation of sucrose response thresholds in honey bees (Apis mellifera L.): influence of genotype, feeding and foraging experience, $\mathrm{J}$. Comp. Physiol. A 187, 293-301.

Ray S., Ferneyhough B. (1997) Seasonal variation of proboscis extension reflex conditioning in the honey bee (Apis mellifera), J. Apic. Res. 34, 8183.

Scheiner R., Erber J., Page R.E. (1999) Tactile learning and the individual evaluation of the reward in honey bees (Apis mellifera L.), J. Comp. Physiol. A 185, 1-10.

Scheiner R., Page R.E., Erber J. (2001a) Responsiveness to sucrose affects tactile and olfactory learning in preforaging honey bees of two genetic strains, Behav. Brain Res. 120, 67-73.

Scheiner R., Page R.E., Erber J. (2001b) The effects of genotype, foraging role and sucrose perception on the tactile learning performance of honey bees (Apis mellifera L.), Neurobiol. Learn. Mem. 76, $138-150$

Seeley T.D. (1995) The wisdom of the hive, Harvard University Press, Cambridge Mass, London.

Takeda K. (1961) Classical conditioned response in the honey bee, J. Insect Physiol. 6, 168-179.

Thorn R.S., Smith B.H. (1997) The olfactory memory of the honeybee Apis mellifera. III. Bilateral sensory input is necessary for induction and expression of olfactory blocking, J. Exp. Biol. 200, 2045-2055.

Winston M.L. (1987) The biology of the honey bee, Harvard University Press, Cambridge Mass., 